\title{
PERBEDAAN PERKEMBANGAN MOTORIK BALITA STUNTING DAN NORMAL DI WILAYAH KERJA PUSKESMAS PEGANG BARU
}

\author{
Eka Putri Primasari ${ }^{1}$, Putri Nelly Syofiah $^{2}$, Gina Muthia $^{3}$ \\ Prodi D III Kebidanan ${ }^{1}$, Prodi S-1 Kebidanan ${ }^{2,3}$ \\ STIKes MERCUBAKTIJAYA Padang \\ ekaputrips@yahoo.com¹, putrinelly8@gmail.com²
}

\begin{abstract}
WHO data for 2019 states, that 21.3\% of all toddlers in the world are stunted. In Indonesia, it is known that $11.5 \%$ of toddlers are very short and $19.3 \%$ are short. In West Sumatra, there are $9.6 \%$ very short children under five and $20.3 \%$ short children. The percentage of stunting cases in Pasaman Regency was $25.1 \%$ and stunting cases was quite high in the working area of Puskesmas Pegang Baru, Pasaman Regency (16.8\%). The results of the preliminary survey on growth and development monitoring of 5 stunting toddlers in the working area of Puskesmas Pegang Baru, found that 2 of them experienced dubious fine motoric and gross motoric development. This study aims to analyze the differences in motor development between stunting and normal toddlers in the working area of Puskesmas Pegang Baru, Pasaman Regency. This type of research is analytic with the approach used cross sectional study. The number of samples in the study were 130 toddlers. Motor development data were obtained through the KPSP format. The statistical test used was the chi square test. The results showed that there were differences in the development of fine motoric ( $p$-value $=0,000$ ) and gross motoric ( $p$-value $=0.002$ ) between stunting and normal toddlers. It is hoped that the Puskesmas will be more active in monitoring the growth and development of toddlers, especially those with stunting. So that if irregularities / doubts are found, help measures can be immediately given to minimize the disturbance of growth and development in toddlers.
\end{abstract}

Keywords $\quad$ : Fine Motoric, Gross Motoric, Stunting

\begin{abstract}
ABSTRAK
Data WHO tahun 2019 menyebutkan 21,3\% dari semua balita di dunia mengalami stunting. Di Indonesia diketahui terdapat 11,5\% balita sangat pendek dan 19,3\% balita pendek. Di Sumatera Barat terdapat $9,6 \%$ balita sangat pendek dan $20,3 \%$ balita pendek. Persentase kasus stunting di Kabupaten Pasaman yaitu $25,1 \%$ dan Kasus stunting cukup tinggi di wilayah kerja Puskesmas Pegang Baru, Kabupaten Pasaman yaitu $16,8 \%$. Hasil survey pendahuluan pemantauan tumbuh kembang terhadap 5 balita stunting yang bertempat tinggal di wilayah kerja Puskesmas Pegang Baru, didapatkan 2 diantaranya mengalami perkembangan motorik halus dan motorik kasar meragukan. Penelitian ini bertujuan menganalisis perbedaan perkembangan motorik antara balita stunting dan balita normal di wilayah kerja Puskesmas Pegang Baru Kabupaten Pasaman. Jenis penelitian ini bersifat analitik dengan pendekatan yang digunakan adalah cross sectional study. Jumlah sampel dalam penelitian sebanyak 130 balita. Data perkembangan motorik diperoleh melalui format KPSP. Uji statistik yang digunakan adalah uji chi square. Hasil penelitian didapatkan adanya perbedaan perkembangan motorik halus ( $\mathrm{p}$-value $=0,000)$ dan motorik kasar ( $\mathrm{p}$-value $=0,002)$ antara balita stunting dengan balita normal. Diharapkan bagi Puskesmas lebih gencar melakukan pemantauan tumbuh kembang balita, terutama kepada balita stunting. Sehingga jika ditemukan penyimpangan / keraguan dapat segera diberikan tindakan pertolongan guna meminimalkan terjadinya gangguan terhadap tumbuh kembang pada balita.
\end{abstract}

Kata Kunci : Motorik Halus, Motorik Kasar, Stunting 


\section{PENDAHULUAN}

Data Global Health Observatory (GHO) World Health Organization (WHO) menunjukkan $21,3 \%$ dari semua anak di bawah 5 tahun di dunia mengalami stunting pada 2019 (World Health Organization, 2020a). Diketahui prevalensi stunting untuk wilayah South-eastern Asia tahun 2020 adalah 24,1 (18 - 31,5) dengan perkiraan jumlah kasus stunting sebanyak 13,5 juta $(10,1$ - 17,6) (World Health Organization, 2020b). Data Profil Kesehatan Indonesia tahun 2019 menunjukkan, di Indonesia persentase balita usia 0-59 bulan yang sangat pendek $(11,5 \%)$ dan balita pendek $(19,3 \%)$. Kondisi ini meningkat dari tahun sebelumnya yaitu persentase balita usia 059 bulan sangat pendek sebesar 9,8\% dan balita pendek sebesar $19,8 \%$.

Di Sumatera Barat, tahun 2018 persentase balita usia 0-59 bulan yang sangat pendek $(9,6 \%)$ dan balita pendek (20,3\%) (Kementerian Kesehatan Indonesia, 2020). Persentase kasus stunting untuk di Kabupaten Pasaman yaitu 25,1\% (Dinas Kesehatan Provinsi Sumatera Barat, 2018). Berdasarkan data status gizi balita di Kabupaten Pasaman, dari 12 Kecamatan yang ada, Kecamatan Panti dengan salah satu Puskesmasnya adalah Puskesmas Pegang Baru memiliki persentase cukup tinggi yaitu 16,8\% (Dinas Kesehatan Kab. Pasaman, 2018).

Pada masa balita perkembangan kemampuan berbahasa, kreativitas, kesadaran sosial, emosional dan intelegensia berjalan sangat cepat merupakan landasan perkembangan berikutnya, sehingga setiap kelainan atau penyimpangan sekecil apapun apabila tidak terdeteksi apalagi tidak ditangani dengan baik, akan mengurangi kualitas sumber daya manusia kelak kemudian hari (Soetjiningsih dan IG.N.Gde Ranuh, 2013).

Periode emas dalam kehidupan balita dicirikan oleh pertumbuhan dan perkembangan yang berlangsung pesat tapi rentan terhadap kekurangan gizi sehingga diperlukan deteksi sedini mungkin. Deteksi dini dapat dilakukan melalui penilaian pertumbuhan fisik dan penilaian perkembangan motorik anak. Penilaian perkembangan motorik dapat dideteksi dengan menggunakan instrumen khusus yaitu Kuesioner Pra Skrining Perkembangan (KPSP) (Sukesi, Rina and Emilia, 2011).

Untuk mengoptimalkan tumbuh kembangnya setiap balita diberikan stimulasi sebagai kegiatan merangsang kemampuan dasar anak yang dapat dilakukan oleh ibu, bapak dan anggota keluarga lainnya. Jaringan otak anak yang banyak mendapat stimulasi akan berkembang mencapai $80 \%$ pada usia 3 tahun. Jika anak tidak pernah diberi stimulasi maka jaringan otak akan menurun. Hal ini dapat mengurangi kualitas sumber daya manusia dimasa yang akan datang (Soetjiningsih dan IG.N.Gde Ranuh, 2013).

Stunting diakibatkan oleh terjadinya kekurangan zat gizi (khususnya energi lemak dan protein) jangka panjang. Hal tersebut akan menghambat proses pembentukan dan pematangan jaringan otot, sehingga kemampuan mekanik otot berkurang dan menyebabkan rendahnya kemampuan motorik. Stunting pada usia dibawah lima tahun (balita) dapat menyebabkan gangguan perkembangan seperti perkembangan motorik, kognitif, bahasa dan personal sosial. Ini disebabkan karena pada usia 5 tahun pertama perkembangan vital terjadi pada seluruh bagian otak yang mempengaruhi perkembangan motorik, kognitif dan sosioemosional (Grantham-mcgregor et al., 2007). Penelitian Yulianti menemukan ada hubungan antara stunting dengan perkembangan motorik halus dan motorik kasar pada anak (Yulianti and Rahmawati, 2019).

Hasil survey pendahuluan pemantauan tumbuh kembang terhadap 5 balita stunting yang bertempat tinggal di wilayah kerja Puskesmas Pegang Baru, didapatkan 2 
diantaranya mengalami perkembangan motorik halus dan motorik kasar meragukan. Berdasarkan permasalahan tersebut maka perlu diadakan penelitian yang bertujuan untuk menganalisis perbedaan perkembangan motorik antara balita stunting dan balita normal di wilayah kerja Puskesmas Pegang Baru.

\section{METODE}

Metode yang digunakan dalam penelitian ini adalah penelitian analitik dengan desain cross sectional. Penelitian ini dilaksanakan di wilayah kerja Puskesmas Pegang Baru Kabupaten Pasaman, pengumpulan data dilakukan pada tanggal 10-13 Agustus 2020. Populasi dalam penelitian ini adalah semua balita yang bertempat tinggal di wilayah kerja Puskesmas Pegang Baru Kabupaten Pasaman yang berjumlah 396 orang balita dengan sampel yang berjumlah 130 orang balita. Teknik pengambilan sampel dalam penelitian ini adalah accidental sampling. Pengumpulan data dilakukan dengan cara observasi kepada semua sampel dengan menggunakan panduan format Kuesioner Pra Skrinning Perkembangan (KPSP). Pengolahan data dilakukan dengan cara editing, coding, entry, tabulating dan cleaning. Analisa data dalam penelitian ini ialah secara bivariat dengan uji chi square.

\section{HASIL}

\section{Perbedaan Perkembangan Motorik} Halus Balita Stunting dan Normal di Wilayah Kerja Puskesmas Pegang Baru

Dari tabel 1 dapat diketahui bahwa dari 24 orang balita yang terdeteksi mengalami penyimpangan/ meragukan perkembangan motorik halusnya, sebagian besar $(79,2 \%)$ diantaranya ialah balita stunting. Hasil uji statistik menunjukkan adanya perbedaan perkembangan motorik halus antara balita stunting dengan balita normal dengan $p$ value $=0,000(95 \% \mathrm{CI}=3,785-32,664)$.

$$
\text { Hasil analisis perbedaan }
$$
perkembanagn motorik halus balita stunting dan balita normal di wilayah kerja Puskesmas Pegang Baru dapat dilihat pada tabel berikut ini:

Tabel 1. Perbedaan Perkembangan Motorik Halus Balita Stunting dan Normal di Wilayah Kerja Puskesmas Pegang Baru

\begin{tabular}{ccccc}
\hline $\begin{array}{c}\text { Perkemba- } \\
\text { ngan } \\
\text { Motorik } \\
\text { Halus }\end{array}$ & $\begin{array}{c}\text { Stunting } \\
\text { f } \\
(\%)\end{array}$ & $\begin{array}{c}\text { Normal } \\
\mathbf{f}\end{array}$ & $\begin{array}{c}\text { Total } \\
\mathbf{f}\end{array}$ & $\begin{array}{c}\text { p-value } \\
(\boldsymbol{\%})\end{array}$ \\
\hline $\begin{array}{c}\text { Penyim- } \\
\text { pangan/ }\end{array}$ & 19 & 5 & 24 & \\
Meragukan & $(79,2)$ & $(20,8)$ & $(100)$ & 0,000 \\
Normal & 27 & 79 & 106 & $32,664)$ \\
sesuai umur & $(25,5)$ & $(74,5)$ & $(100)$ & \\
\hline Total & 46 & 84 & 130 & \\
\hline & $(35,4)$ & $(64,6)$ & $(100)$ & \\
\hline
\end{tabular}

\section{Perbedaan Perkembangan Motorik Kasar Balita Stunting dan Normal di Wilayah Kerja Puskesmas Pegang Baru Hasil analisis perbedaan perkembangan motorik kasar balita stunting dan balita normal di wilayah kerja Puskesmas Pegang Baru dapat dilihat pada tabel berikut ini:}

\section{Tabel 2. Perbedaan Perkembangan Motorik Kasar Balita Stunting dan Normal di Wilayah Kerja Puskesmas Pegang Baru}

\begin{tabular}{|c|c|c|c|c|}
\hline \multirow{2}{*}{$\begin{array}{c}\text { Perkemba- } \\
\text { ngan } \\
\text { Motorik } \\
\text { Kasar }\end{array}$} & \multicolumn{2}{|c|}{ Stunting } & \multirow[b]{2}{*}{$\begin{array}{c}\text { Total } \\
\mathbf{f} \\
(\%)\end{array}$} & \multirow[b]{2}{*}{$\begin{array}{c}\text { p-value } \\
(95 \% \mathrm{CI})\end{array}$} \\
\hline & $\begin{array}{c}\text { Stunting } \\
\mathbf{f} \\
(\%)\end{array}$ & $\begin{array}{c}\text { Normal } \\
\mathbf{f} \\
(\%)\end{array}$ & & \\
\hline $\begin{array}{c}\text { Penyimpa- } \\
\text { ngan/ } \\
\text { Meragukan }\end{array}$ & $\begin{array}{l}18 \\
(60)\end{array}$ & $\begin{array}{c}12 \\
(40)\end{array}$ & $\begin{array}{c}30 \\
(100)\end{array}$ & $\begin{array}{c}0,002 \\
(1,647-\end{array}$ \\
\hline $\begin{array}{c}\text { Normal } \\
\text { sesuai umur }\end{array}$ & $\begin{array}{c}28 \\
(28)\end{array}$ & $\begin{array}{c}72 \\
(72)\end{array}$ & $\begin{array}{c}100 \\
(100)\end{array}$ & $9,033)$ \\
\hline Total & $\begin{array}{c}46 \\
(35,4)\end{array}$ & $\begin{array}{c}85 \\
(64,6)\end{array}$ & $\begin{array}{c}130 \\
(100)\end{array}$ & \\
\hline
\end{tabular}

Dari tabel 2 di atas dapat diketahui bahwa dari 30 orang balita yang terdeteksi mengalami penyimpangan/ meragukan perkembangan motorik kasarnya, lebih dari setengah $(60 \%)$ diantaranya ialah balita stunting. Hasil uji statistik menunjukkan 
adanya perbedaan perkembangan motorik kasar antara balita stunting dengan balita normal dengan $p$-value $=0,002(95 \% \mathrm{CI}=$ 1,647 - 9,033).

\section{PEMBAHASAN}

\section{Pembahasan Motorik Halus}

Hasil penelitian menunjukkan adanya perbedaan perkembangan motorik halus antara balita stunting dengan balita normal di wilayah kerja Puskesmas Pegang Baru dengan $p$-value $=0,000(95 \% \mathrm{CI}=3,785$ $32,664)$. Hasil penelitian ini sama dengan penelitian yang dilakukan oleh Yulianti, Dyah (2019) berjudul Hubungan Status Stunting dengan Perkembangan pada Anak Usia Pra Sekolah di Wilayah Kerja Puskesmas Kemumu Kabupaten Bengkulu Utara yang menyatakan bahwa terdapat hubungan yang signifikan antara stunting dengan perkembangan motorik halus ( $p$ value $=0,003$ ) (Yulianti and Rahmawati, 2019).

Balita yang stunting (pendek) akan mengalami pertumbuhan rangka yang lambat dan pendek. Keadaan ini terjadi karena tidak terpenuhinya kebutuhan makanan dan meningkatnya angka kesakitan pada balita yang terjadi dalam jangka waktu yang lama. Pertumbuhan dan perkembangan sel-sel otak dipengaruhi oleh zat gizi yang dikonsumsi oleh balita dalam dua tahun pertama kehidupannya. Apabila dalam dua tahun pertama balita mendapatkan nutrisi yang adekuat maka pertumbuhan rangkanya akan cepat dan tidak pendek (Angdembe et al., 2019).

Perkembangan adalah bertambahnya struktur dan fungsi tubuh yang lebih kompleks dalam kemampuan gerak kasar, gerak halus, bicara dan bahasa serta sosial dan kemandirian (Kementerian Kesehatan Indonesia, 2016). Penelitian yang dilakukan oleh Hanani (2016) yang berjudul Perbedaan Perkembangan Motorik Kasar, Motorik Halus, Bahasa dan Personal Sosial pada Anak Stunting dan Non Stunting menyatakan bahwa $16,3 \%$ anak yang stunting memiliki perkembangan motorik halus yang mencurigakan (Ruth Hanani dan Ahmad Syauqy, 2016). Kemampuan motorik yang rendah pada anak stunting terjadi karena terhambatnya proses kematangan otot yang menyebabkan kemampuan mekanik otot berkurang (Solihin Rindu Dwi Malateki, Faisal Anwar, 2013).

Anak yang memiliki tinggi badan yang normal dan otot yang kuat akan lebih cepat menguasai gerakan-gerakan motorik halus dan kasar jika dibandingkan dengan anak yang memiliki tinggi badan yang kurang diantara anak-anak seusianya (Yulianti and Rahmawati, 2019). Penelitian yang dilakukan oleh Solihin, Anwar, Sukandar (2013) yang berjudul Kaitan Antara Status Gizi, Perkembangan Kognitif, Perkembangan Motorik Pada Anak Usia Prasekolah menyatakan bahwa semakin meningkat status gizi balita maka akan meningkat pula tingkat perkembangan motorik halus balita tersebut dan sebaliknya. (Solihin Rindu Dwi Malateki, Faisal Anwar, 2013).

Menurut Levitsky, 1979 dalam Solihin, 2013, Anak yang stunting (pendek) akan mengalami kehilangan rasa ingin tahu terhadap lingkungannya sehingga gagal dalam mencapai perkembangan motorik halus jika dibandingkan dengan anak yang normal. Menurut Thelen, 1995 dalam Solihin, 2013, kemampuan motorik halus mulai berkembang sejak pertama kelahiran dan berkembang secara bersamaan dalam tingkat yang bervariasi yang dipengaruhi oleh interaksi bayi dengan lingkungannya (Solihin Rindu Dwi Malateki, Faisal Anwar, 2013).

\section{Pembahasan Motorik Kasar}

Pengurukuran perkembangan motorik kasar pada penelitian ini menggunakan KPSP. Dari hasil pengukuran perkembangan motorik kasar pada balita yang menjadi responden didapatkan hasil pemeriksaan dari 30 orang balita yang terdeteksi mengalami penyimpangan/ meragukan perkembangan motorik 
kasarnya, lebih dari setengah (60\%) diantaranya ialah balita stunting. Dikatakan hasil meragukan, bila pada satu sektor didapatkan dua keterlambatan atau lebih, dan bila pada satu sektor didapatkan satu keterlambatan dan pada sektor yang sama tidak ada yang lulus pada kotak yang berpotongan dengan garis vertikal usia. Perkembangan motorik kasar balita sebagian besar meragukan/ menyimpang di karenakan adanya keterlambatan, dimana balita belum melewati tugas perkembangan dengan baik sesuai usianya (Kementerian Kesehatan Indonesia, 2016). Hasil penelitian ditemukan adanya perbedaan perkembangan motorik kasar antara balita stunting dengan balita normal di wilayah kerja Puskesmas Pegang Baru dengan ( $p$ value $=0,002)$. Hal ini sebanding dengan penelitian Yulianti tahun 2019, dimana hasil uji statistiknya menunjukkan ada hubungan yang signifikan antara stunting dengan perkembangan motorik kasar (pvalue $=0,004)$ pada anak prasekolah (Yulianti and Rahmawati, 2019).

Perkembangan motorik kasar balita dipengaruhi oleh organ otak pada balita. Semakin matangnya perkembangan sistem saraf otak balita yang mengatur sistem saraf otak balita memungkinkan berkembangnya kemampuan motorik kasar pada balita. Balita yang mengalami gangguan kemampuan motorik kasar pada masa balita, akan berdampak mengalami gangguan tumbuh kembang selama masa balita, sehingga menyebabkan efek yang menetap pada usia dewasanya (Soetjiningsih dan IG.N.Gde Ranuh, 2013). Peneliti berasumsi bahwa balita yang mengalami stunting akan mempengaruhi pada perkembangan motorik halus/kasar balita. Pemantauan pertumbuhan dan perkembangan balita sesuai usia sangatlah diperlukan. Kecerdasaran motorik halus/kasar yang baik dapat meningkatkan kualitas hidup balita di masa depannya.

\section{KESIMPULAN}

Berdasarkan hasil dapat disimpulkan bahwa terdapat perdedaan perkembangan motrik halus dan motorik kasar antara balitadan balita normal di wilayah kerja Puskesmas Pegang Baru. Oleh karena itu sangat diperlukan pemantauan pertumbuhan dan perkembangan balita secara rutin sesuai dengan usia balita. Diharapkan bagi Puskesmas lebih gencar melakukan pemantauan tumbuh kembang balita, terutama kepada balita stunting. Sehingga jika ditemukan penyimpangan/keraguan dapat segera diberikan tindakan pertolongan guna meminimalkan terjadinya gangguan terhadap tumbuh kembang pada balita.

\section{UCAPAN TERIMAKASIH}

Dalam penelitian ini, peneliti banyak mendapatkan bantuan dari berbagai pihak. Sehubungan dengan hal tersebut peneliti mengucapkan terima kasih kepada Kemenristek/BRIN, Puskesmas Pegang Baru Kabupaten Pasaman dan LPPM STIKes MERCUBAKTIJAYA Padang.

\section{DAFTAR PUSTAKA}

Angdembe, M. R. et al. (2019) 'Trends and predictors of inequality in childhood stunting in Nepal from 1996 to 2016', International Journal for Equity in Health. International Journal for Equity in Health, pp. 1-17. doi: 10.1186/s12939-019-0944-z.

Dinas Kesehatan Kab. Pasaman (2018) Laporan Status Gizi Balita dan Data Indikator Gizi. Pasaman. Kabupaten Pasaman.

Dinas Kesehatan Provinsi Sumatera Barat (2018) Laporan Status Gizi Balita dan Data Indikator Gizi Kab/Kota. Padang. 
Grantham-mcgregor, S. et al. (2007) 'Child development in developing countries 1 Developmental potential in the fi rst 5 years for children in', Lancet, 369. doi: 10.1016/S0140-6736(07)600324.

Kementerian Kesehatan Indonesia (2016) Pedoman Pelaksanaan Stimulasi, Deteksi dan Intervensi Dini Tumbuh Kembang Anak. Jakarta: Kemenkes RI.

Kementerian Kesehatan Indonesia (2020) Profil Kesehatan Indonesia. Jakarta: Kemenkes RI. Available at: https://pusdatin.kemkes.go.id/resourc es/download/pusdatin/profilkesehatan-indonesia/ProfilKesehatan-indonesia-2019.pdf.

Ruth Hanani dan Ahmad Syauqy (2016) 'Journal of Nutrition College', Journal of Nutrition College, 5(Jilid 3), pp. 412-418. Available at: https://ejournal3.undip.ac.id/index.ph p/jnc/article/view/16452/15852.

Soetjiningsih dan IG.N.Gde Ranuh (2013) Tumbuh Kembang Anak. 2nd edn. Jakarta: EGC.

Solihin Rindu Dwi Malateki, Faisal Anwar, D. S. (2013) 'Kaitan Antara Status Gizi, Perkembangan Kognitif, Perkembangan Motorik Pada Anak Usia Prasekolah', Penelitian Gizi dan Makanan, 36(1), pp. 62-72. Available at: http://ejournal.litbang.kemkes.go.id/i ndex.php/pgm/article/view/3396/338
7.

Sukesi, N., Rina, D. and Emilia, K. (2011) 'Tumbuh Kembang Anak Di Posyandu'.

World Health Organization (2020) Child stunting Global Health Observatory (GHO) data, World Health Organization. Available at: https://www.who.int/gho/childmalnutrition/stunting/en/ (Accessed: 20 November 2020).

World Health Organization (2020b) Stunting Prevalence Stunting global and regional trends jme-(unicef-whowb), World Health Organization. Available at: who.int/data/gho/data/themes/topics/i ndicator-groups/indicator-groupdetails/GHO/gho-jme-global-andregional-trends-stunting-jme-unicefwho-wb (Accessed: 20 November 2020).

Yulianti, S. and Rahmawati, D. T. (2019) 'Hubungan Status Stunting dengan Perkembangan pada Anak Usia Pra Sekolah di Wilayah Kerja Puskesmas Kemumu Kabupaten Bengkulu Utara', Prosiding Seminar Nasional Teknologi Informasi Komputer dan Sains 2019, pp. 372-381. Available at:

http://sintaks.kitamenulis.id/index.ph p/Sintaks/article/view/47/pdf_1. 